\title{
難治性前頭洞囊胞に対する充填術の検討
}

\author{
長崎大学大学院医歯薬学総合研究科病態解析・制御学講座耳鼻咽喉病態制御学領域 \\ 海江田哲，高 野篤, \\ 畑 地 憲輔, 高 橋 晴 雄
}

\section{Sinus Obliteration with Bone Pate and Hydroxyapatite in Treatmenting Recurrent Frontal Sinus Mucocele}

\author{
Satoru Kaieda, Atsushi Takano, Kensuke Hatachi, \\ Haruo Takahashi
}

\begin{abstract}
Department of Otorhinolaryngology, Graduate School of Life and Medical Sciences, Nagasaki University, Nagasaki
\end{abstract}

\begin{abstract}
Surgical treatment of frontal sinus mucocele is divided into (i) establishment of frontal sinus drainageand (ii) sinus obliteration after total mucocele removal. Advances in endoscopic sinus surgery have made it possible to manage most frontal sinus mucoceles safely and successfully by endonasal procedures, but some cases can not have stable drainage established or the specific sinus pathology is beyond the operating field of endonasal frontal sinus surgery. These cases require an external approach to remove the mucocele and sinus obliteration. We report two cases of frontal sinus mucoceles recurrent after 3 times endonasal frontal drainages. Total removal of mucocele with coronal incision and frontal sinus obliteration with autogenous bone pate and hydroxypatite were conducted. One patient remains event-free for 8 months postoperatively and the other 17 month postoperatively with no significant complications. In this report, we discuss the role of the external approach and the usefulness of sinus obliteration with bone pate and hydroxyapatite for treatment of the recurrent frontal sinus mucocele.
\end{abstract}

Key words : frontal sinus mucocele, sinus obliteration, bone pate, hydroxyapatite

\section{はじめに}

前頭洞囊胞に対する手術法は，1）襄胞の開放と 2) 囊胞の全摘の 2 つに大別される。近年, 内視鏡下鼻副鼻 腔手術（Endoscopic Sinus Surgery；ESS）の発達に伴 い，鼻内アプローチによる低侵襲かつ確実な襄胞の解放 が可能となり, 多くの症例における術式の第一選択とな

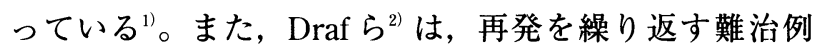
に対して, 顕微鏡を併用し前頭洞中隔と鼻中隔上部を合 併切除, 左右の前頭洞底を広く開放する術式（Draf type III）の有効性を報告している。本邦でも黄川田ら ${ }^{3)} に よ$ る追試以来普及しつつある術式である。しかし, 前頭洞
はその解剖学的位置から，大きく鼻腔へ開放するには熟 練した技術を要する。更に，いずれの術式も襄胞を残存 させるため開放部の再閉塞による再発の可能性が否定で きない。再発防止策として長期間にわたるチューブ留置 など様々な工夫が行われているにも関わらず再発率の高 い疾患である。これに対し, 襄胞の摘出は, 外切開を必 要とするため, やや侵襲の大きな術式ではあるが, 疾患 の根治を目指した術式であり，原則として再発の可能性 は非常に低い。

今回我々は, 過去 3 回にわたる鼻内への開放後に再発 した難治性前頭洞囊胞 2 症例に対し, 外切開（冠状切 開）による囊胞の摘出と前頭骨より採取した自家骨粉及 


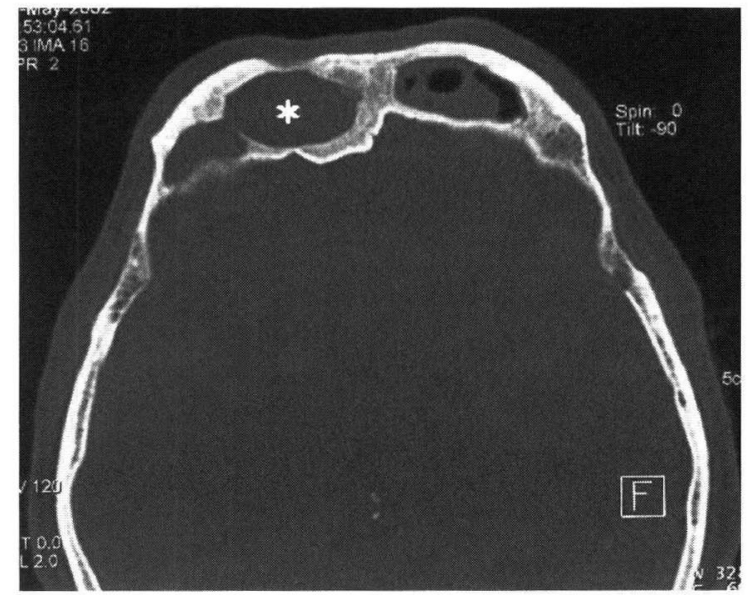

a

図 1 症例 1 術前 CT ( a . 水平断, b. 冠状断) 右眼窝上壁は囊胞 $(*)$ の庄迫により広く消失 (矢印)。眼窝内に大きく突出した囊胞により, 眼球 は強く下方に压排されている。

びセラミック人工骨による充填術を施行し良好な結果を 得ることができた。そこで，この 2 症例を提示し，本術 式の特徵について考察を加える。

\section{症 例 呈示}

症例 $1 ： 56$ 歳, 男性

主訴：右眼球の下方偏位, 上方視時の復視

現病歴：35年前, 副鼻腔炎に対し両鼻内術を受けた。 平成 5 年, 右眼球の下方偏位及び上方視時の復視が出現 し当科初診，右前頭洞囊胞の診断下に鼻外切開による副 鼻腔開放術を受けた。しかし，5 月月後には症状再発， 以降，平成 7 年に鼻内術，平成13年には，鼻内法と鼻外 切開による副鼻腔開放術を併用し，前頭洞中隔を穿破し 左前頭洞と交通をつけ，左鼻腔に開放のうえ，左鼻前頭 管にドレーンを留置したが, ドレーンは術後 1 カ月で自 然脱落し, 6 力月後には症状が再発した。今回, 患者と 相談のうえ, 冠状切開による囊胞摘出及び充填術目的に て入院となった。

現症：右前頭部に軟性の腫瘤を認め, 右眼球の外下方 への偏位を認めた。眼科的には, 右眼の上転及び内転障 害に伴う復視を認めるも, 視野欠損や眼底異常は無から た。

画像所見：術前副鼻腔 CT（図 1) では, 右前頭洞に 囊胞を認め, その囊胞の圧迫により右眼窩上壁は広く欠 損し, 更に, 眼窩内に大きく突出した囊胞により眼球は 強く下方に圧排されていた。

手術所見：平成14年 6 月 6 日，全身麻酔下に手術を施 行した。術前にドップラー法を用いてマーキングしてお いた浅側頭動脈の走行に注意し頭皮冠状切開を行い，骨

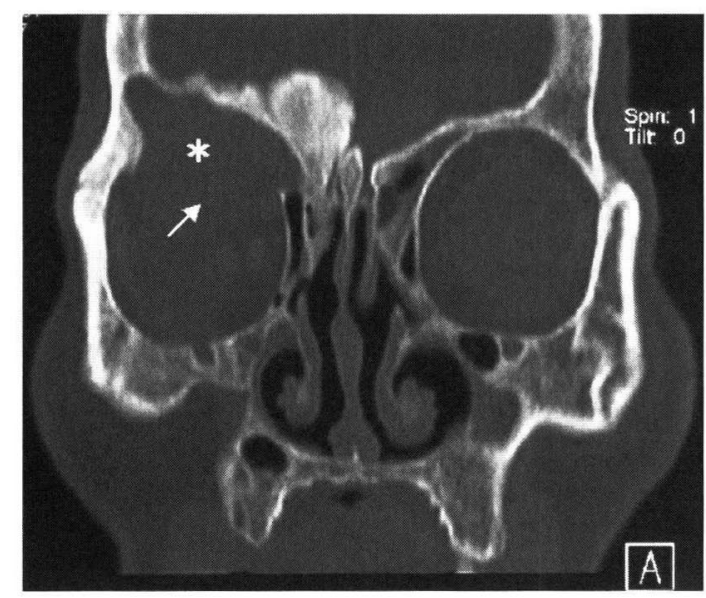

b

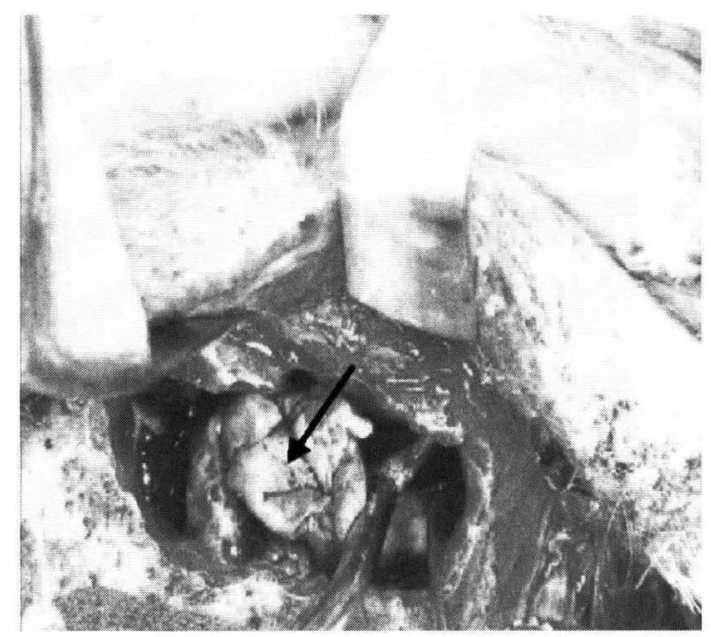

図 2 症例 1 手術所見（囊胞の摘出） 冠状切開後，前頭洞を広く開空し，囊胞壁 を骨面より剥離摘出した（矢印）。

膜下で皮弁を挙上し前頭骨を広く露出させた。前回開空 部で囊胞を確認の後, 前頭洞を広く開空し, 前頭洞骨面 および強く癒着した眼窝骨膜より囊胞壁を注意深く剥離 し囊胞を摘出した（図 2 )。続いて, 広く露出した前頭 骨前壁よりバーを用いて充填材料である自家骨粉を採取 した。この際, 術中頭蓋内損傷及び術後の前頭部の変形 を考虑して，術前 CT（軸位断）で前頭骨前壁の厚さを 確認し, 広範用に均等な厚さ（約 $2 \mathrm{~mm}$ 程度）削開し た。前頭洞内に残存粘膜の無いことを確認し，セラミッ ク人工骨を側方の狭い空間まで充分に充填した（図 3 a ）。更に，眼窩骨膜とセラミック人工骨とが直接接す ることの無いように，採取した骨粉を骨パテとし， 欠損 した眼窩上壁を再建する形で充填した（図 3 b )。 


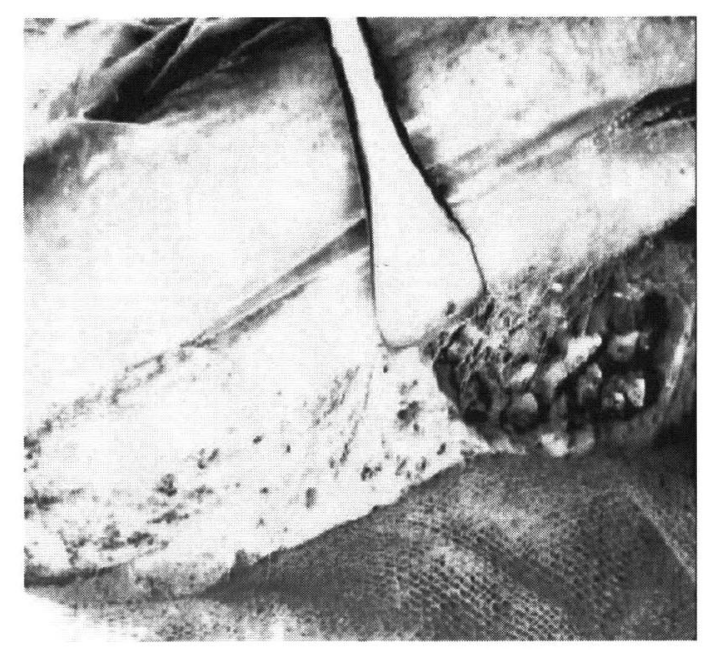

a

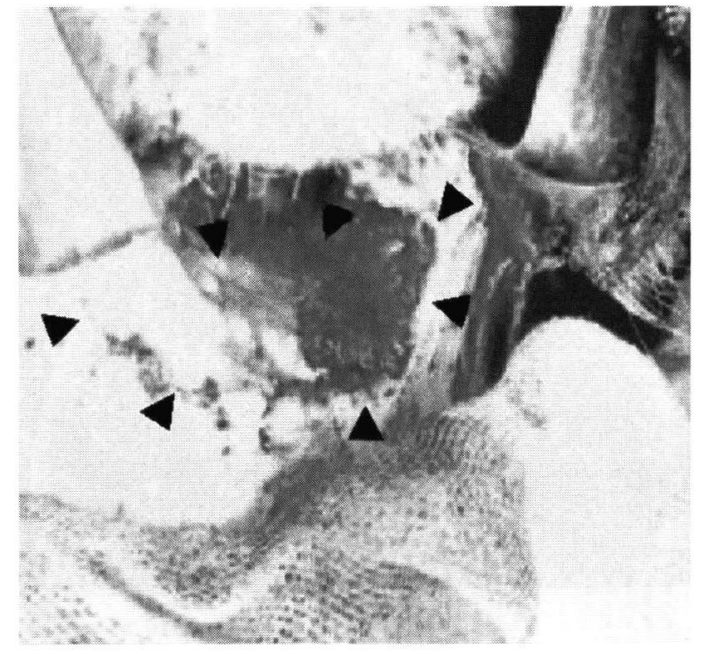

b

図 3 症例 1 手術所見（前頭洞の充填） a 。セラミック人て骨にて囊胞摘出後の前頭洞を充填。

b ．骨パテを用い欠損した眼窩上壁及び前頭洞前壁を再建するように充填 (ムにてホした範囲)。

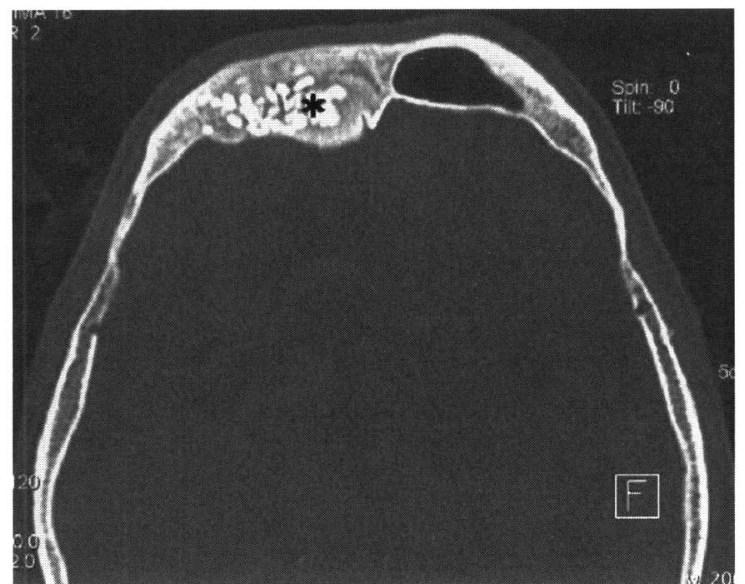

a

図 4 症例 1 術後 CT ( a . 水平断, b. 过状断) 術後12カ月が経過したが，充填した前頭润

術後経過：術後一過性に眼瞼の浮腫を認めた以外には 大きな合併症は無く21日目には退院となった。術後12力 月後の副鼻腔 CTでは充填した前頭洞は完全に器質化 し, 眼位は正常に復し囊胞の再発も認めていない（図 4 )。

\section{症例 $2 ： 42$ 歳, 男性}

\section{主訴：左前頭部の有痛性腫脹}

現病歴： 27 年前に左前頭洞炎に対し, 鼻外切開によ る副鼻腔開放術を受けた。平成 8 年左前頭部の有痛性腫 脹が出現し，同年 6 月，内視鏡下に鼻内へ開放した。そ の後，平成12年及び 13 年に同じく内視鏡下に鼻内への開 放術を受けたがいずれも再発し，今回，患者と相談のう え, 冠状切開による襄胞摘出及び充填術目的にて入院と

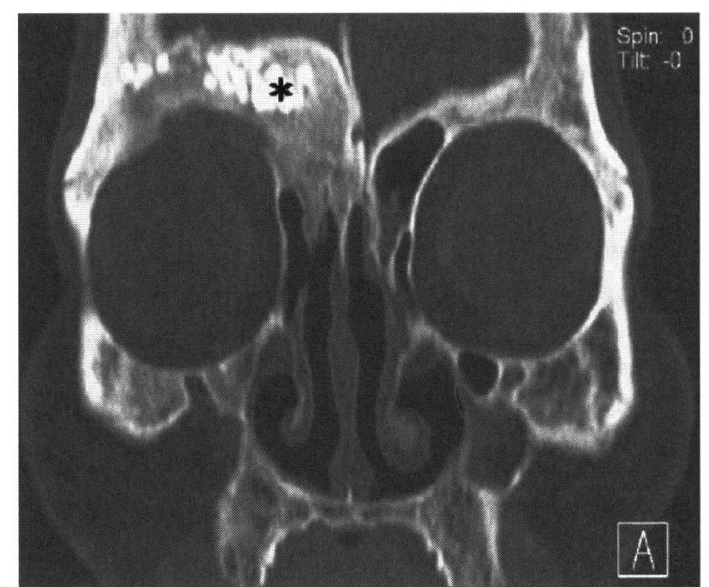

b

（*）の器質化は進行しており, 露胞の再発は認めない。

なった。

現症：左前頭部に軟性で有痛性の腫瘤を認めた。眼科 的には, 視力及び眼球運動障害などの異常所見は認めな かった。

術前画像所見：左前頭洞に賷胞を認めた。前頭洞後壁 に骨欠損を認め，硬膜の露出が疑われた（図 5 )。

手術所見：症例 1 と同様に，全身麻酔下に頭皮冠状切 開により囊胞を摘出した。本症例では，前頭洞後壁に 3 力所の小さな骨欠損を認め, 同部で囊胞壁と硬膜が癒着 していたため,これを鋭的に切除剥離し, 輁胞壁残存の 無いよう留意した。硬膜露出部を結合織にて被覆し, 症 例 1 と同様に，囊胞摘出後の前頭洞をセラミック人工骨 及び自家骨粉にて充填した。 


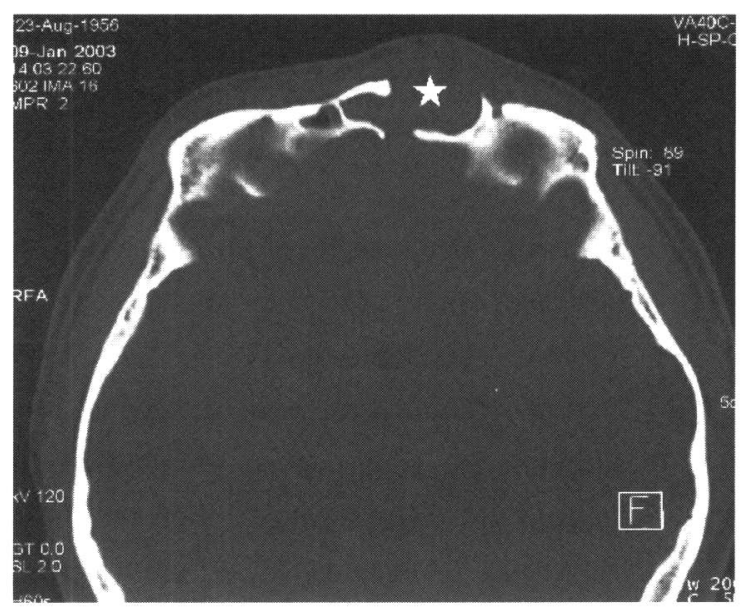

a

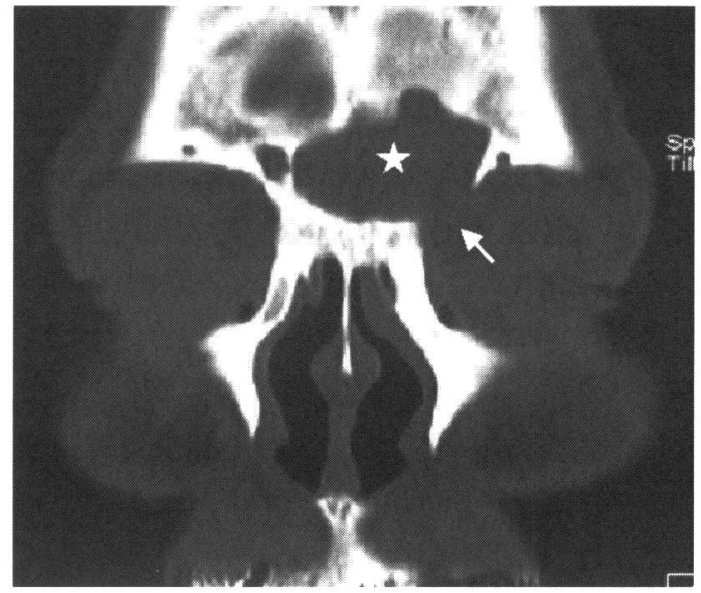

b

図 5 症例 2 術前 CT ( a . 水平断, b. 冠状断)

左前頭洞に囊胞を認める（れ)。前頭洞後壁に数力所の小さな骨欠損を認める。

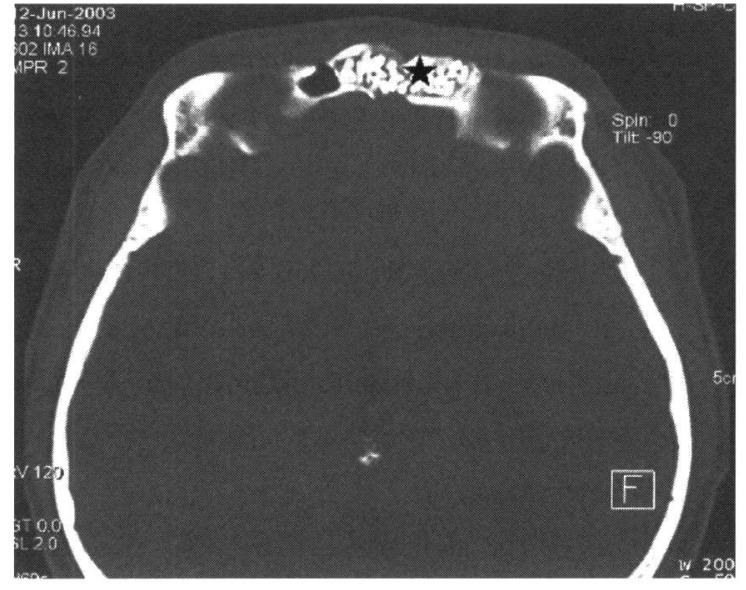

a

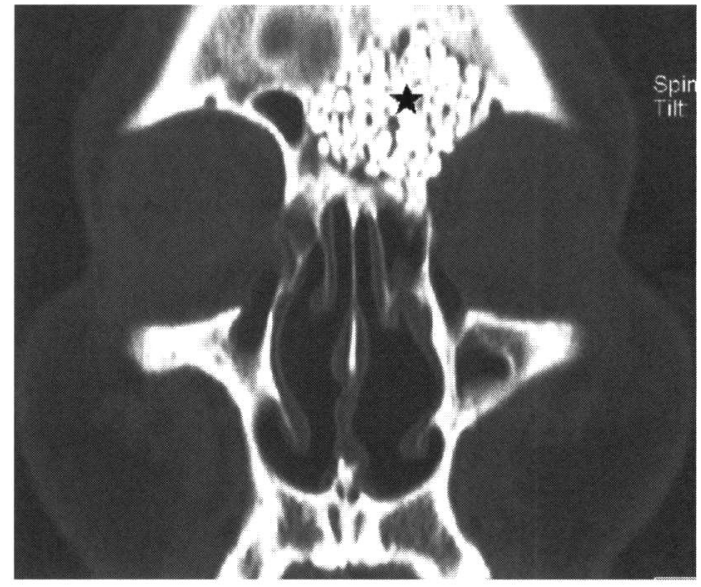

b

図 6 症例 2 術後 $\mathrm{CT}$ ( a . 水平断, b. 毕状断) 術後 7 カ月目の CT では充填した前頭洞は完全に器質化し ( ), 豊胞の再発は認めない。

術後経過：術後経過は良好で特に合併症も無く術後17 日目に退院となった。術後 7 力月後の副鼻腔 CT では充 填した前頭洞は完全に器質化し, 囊胞の再発は認めてい ない(図6)。

\section{考察}

難治性前頭洞囊胞に対する褰胞の摘出及び充填術 は，1950年代には既に確立されている゙”。内視鏡下鼻内 手術の進歩した今日でも，この術式に頼らざるを得ない 症例の報告が散見される ${ }^{5-7)}$ 。今回我々は, 囊胞の摘出 及びその後の充填に際し次の 2 点に工夫した。

\section{1）皮膚切開}

外切開による前頭洞へのアプローチ法は, Killianに より報告された眉毛下縁切開をはじめとして様々な報告
がある い視野の確保が必要であると判断し頭皮冠状切開を用い た。確かに大きな術創ではあるが，これにより広く洞内 を明視下に置くことができ，安全かつ確実な囊胞の摘出 が可能となった。更に，広く露出した前頭骨より骨粉を 採取できる点もこの切開の利点である。

問題点としては, 術中の出血と術後の美容上の問題が あげられる。我々は，出血を最小限に留めるために，術 前に浅側頭動脈の走行をドップラー法を用いて確認して おくこと，側頭筋を損傷しないこと，充分に骨膜下まで 切開を加えることの 3 点に留意した。その結果，出血量 はそれぞれ $120 \mathrm{~mL}$ 及び $90 \mathrm{~mL}$ とさほど問題にならない 量に留めることができた。また, 術後創部は頭髪により 隠れるため, 美容上の観点から考虑しても顔面に切開を 
加える他の方法より有用であると思われた。

2）囊胞摘出後前頭洞の充填材料

通常, 囊胞摘出後の前頭洞の充填材料としては, 腹部 脂肪織, 骨, 軟骨などの遊離組織が用いられることが多

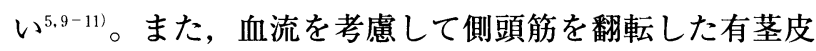
弁が用いられることもある ${ }^{12)}$ 。しかし，これらの材料は 長期的には萎縮することが多い。事実, Weber ら ${ }^{5)}$ は, 腹部より採取した脂肪織を囊胞摘出後の充填材料として 用いた前頭洞充填術51例を対象にMRI を用いて経過観 察し，その53\%（27例）で充填した脂肪織が20\%以下に 縮小していたことを報告している。

今回我々は，前頭骨より採取した骨粉にセラミック人 工骨を併せて充填材料として用いた。これは中耳手術に おける削開後乳突腔の充填材料を前頭洞囊胞に応用した ものであり ${ }^{13)}$ ，(1)細工が容易である，(2)材料の確保に制 限が無い, (3)長期的にも萎縮しない, (4)現存の人工材料 のなかでは異物反応が少ないといった利点を有してい る。確かに, 今回いずれの症例も, 術後 6 力月目には充 填部は完全に基質化し, その後明らかな萎縮は認められ ていない。特に, 症例 1 では広範囲におよぶ眼窩上壁の 骨欠損が認められたが, 術後充填部の基質化により眼位 は正常位に復し症状の再発はみられていない。この事実 は，骨粉をフィブリン糊にて骨パテとし強固に固めるこ とで，広範囲の骨欠損に対しても一期的な骨性再建が可 能であるという本材料の有用性を証明しているものと思 われる。また, 人工材料の欠点として術後感染が挙げら れるが, 症例 2 のように硬膜露出例においても特に問題 なく経過しており, 通常の感染予防で充分対処可能であ ると思われる。

$$
\text { ま と め }
$$

鼻科手術における内視鏡の登場は, 多くの術式に多大 な変化をもたらした。このような時代を背景に, 前頭洞 囊胞に対する豪胞の摘出及び充填術はその侵襲性からや や敬遠される傾向にある。しかし，再発防止の観点から は, 輁胞の完全摘出は最も確実な方法である。確かに今 回の 2 症例の術後観察期間は未だ約 1 年と短く, その長 期的予後に関しては言及できない。今後引き続き経過観 察が必要であると思われる。しかし，今回我々が用いた 術式は，侵襲がやや大きいものの，充分な視野の確保が 可能であり手術操作も比較的容易である。鼻内アプロー チによるドレナージに抵抗し再発する難治性前頭洞囊胞 症例に対する治療法の一つとして考慮されるべき術式で あると思われた。
本論文の要旨は第 42 回日本鼻科学会（平成15年10月, 東京都）にて口演した。

\section{参考文献}

1 ) Kennedy DW, Josephson JS, Zinreich SJ, et al : Endoscopic sinus surgery for mucoceles; a viable alternative. Laryngoscope 99 : 885-895, 1989.

2) Draf W: Endonasal micro-endoscopic frontal sinus surgery; the fulda concept. Operative Techn Otolaryngol Head Neck Surg 2 : 234-240, 1991.

3 ) Kikawada T, Fujigaki M, Kikuura M, et al : Extended endoscopic frontal sinus surgery to interrupted nasofrontal communication caused by scarring of the anterior ethmoid; long-term results. Arch Otolaryngol Head Neck Surg 125: 92-96, 1999.

4) Begara AR: The obliteration of the frontal sinus $s$ in the treatment of frontal chronic sinusitis. Trans Second Pan-Am Conga Otorhinolaryng Bronchoesophagol 1 : 35-45, 1950.

5 ) Weber R, Draf W, Keerl R, et al: Osteoplastic frontal sinus surgery with fat obliteration; technique and long-term results using magnetic resonance imaging in 82 operations. Laryngoscope 110: 10371044, 2000.

6 ）白馬伸洋, 佐伯忠彦, 竹田一彦, 他：開頭術を要し た側頭進展型の前頭洞囊胞例。耳鼻臨床 $89 ： 455^{-}$ 460, 1996.

7 ）生見薰子, 湯本英二, 生塩之敬, 他：側方に進展し た巨大前頭洞囊胞例. 耳鼻臨床 95：815-820, 2002.

8 ) Tato JM, Sibbald DW, Bergaglio OE : Surgical treatment of the frontal sinus by the external route. Laryngoscope 64 : 504-508, 1954.

9) Knauff HA: Single stage frontal sinus obliteration. Arch Otolaryngol 78 : 707-714, 1963.

10) Hardy JM, Montgomery WW ; Osteoplastic frontal sinusotomy; an analysis of 250 operations. Ann Otol Rhinol Laryngol : 523-532, 1976.

11) Catalano PJ, Lawson $W$, Som $P$, et al : Radiographic evaluation and diagnosis of the failed frontal osteoplastic flap with fat obliteration. Otolaryngol Head Neck Surg 104 : 225-234, 1991.

12) Parhiscar A, Har-El G: Frontal sinus obliteration with the pericranial flap. Otolaryngol Head Neck 
Surg $124:$ 304-307, 2001.

13) Gyllencreutz $T$ : Reconstruction of the ear canal wall using hydroxylapatite with and without mastoid obliteration and by obliteration with bone chips. J Laryngol Otol 105 : 417-420, 1991.

（2004年 2 月 23 日受稿, 2004 年 6 月 1 受理）
別刷請求先：海江田 哲

于 852-8501 長崎県長崎市坂本 1-7-1

長崎大学大学院医歯薬学総合研究科病態解析 ·

制御学講座耳鼻咽喉病態制御学領域

Tel : 095-849-7350 Fax : 095-849-7352

E-mail : tetsuumi@aol.com. 